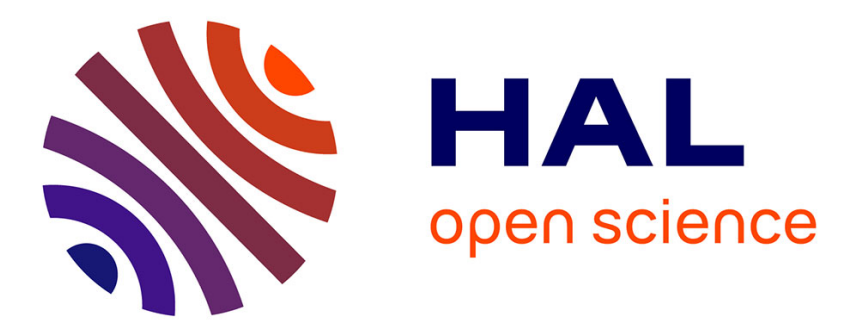

\title{
Hardness Evaluation of Porous Hydroxyapatite Coating
}

\author{
A Behnamghader, B Farsadzadeh, Denis Najjar, Alain Iost
}

\section{To cite this version:}

A Behnamghader, B Farsadzadeh, Denis Najjar, Alain Iost. Hardness Evaluation of Porous Hydroxyapatite Coating. 3rd Kuala Lumpur International Conference on Biomedical Engineering 2006, Dec 2006, Kuala-Lumpur, Malaysia. pp.106-108, 10.1007/978-3-540-68017-8_27 . hal-01314909

\section{HAL Id: hal-01314909 \\ https://hal.science/hal-01314909}

Submitted on 28 Sep 2017

HAL is a multi-disciplinary open access archive for the deposit and dissemination of scientific research documents, whether they are published or not. The documents may come from teaching and research institutions in France or abroad, or from public or private research centers.
L'archive ouverte pluridisciplinaire HAL, est destinée au dépôt et à la diffusion de documents scientifiques de niveau recherche, publiés ou non, émanant des établissements d'enseignement et de recherche français ou étrangers, des laboratoires publics ou privés. 


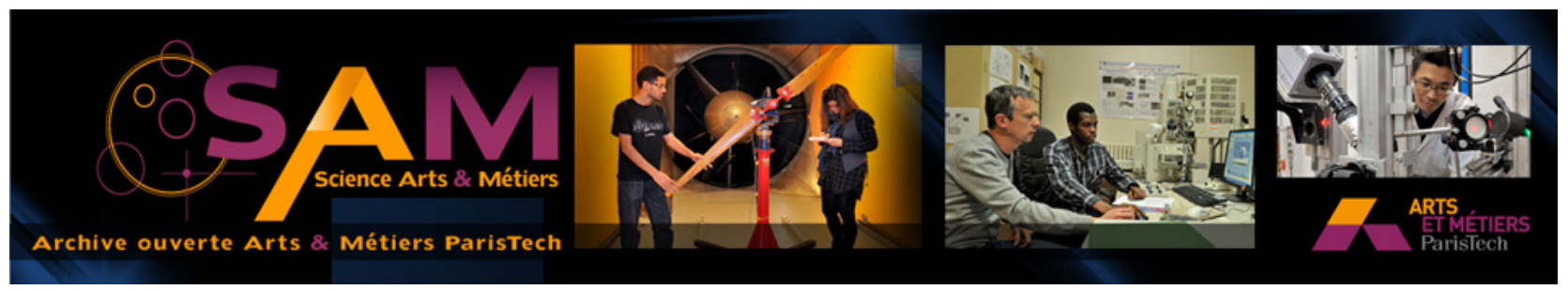

Science Arts \& Métiers (SAM)

is an open access repository that collects the work of Arts et Métiers ParisTech researchers and makes it freely available over the web where possible.

This is an author-deposited version published in: http://sam.ensam.eu

Handle ID: .http://hdl.handle.net/null

\section{To cite this version :}

A BEHNAMGHADER, B FARSADZADEH, Denis NAJJAR, Alain IOST - Hardness Evaluation of Porous Hydroxyapatite Coating - In: 3rd Kuala Lumpur International Conference on Biomedical Engineering 2006, Malaisie, 2006-12-11 - IFMBE Proceedings - 2007 


\title{
Hardness Evaluation of Porous Hydroxyapatite Coating
}

\author{
A. Behnamghader ${ }^{1}$, B. Farsadzadeh ${ }^{2}$, D. Najjar ${ }^{3}$, A. Iost $^{3}$ \\ ${ }^{1}$ Materials and Energy Research center, Tehran, P.O. Box 14155-4777, Iran \\ ${ }^{2}$ Biomedical Department, Azad Islamic University, P.O. Box 14665-1445, Tehran, Iran \\ ${ }^{3}$ ENSAM/LMPGM CNRS UMR 8517, 8 Bd . Louis XIV, 59046 Lille Cedex, France
}

\begin{abstract}
The extensive use of appropriate coatings to improve wear resistance, friction coefficient, electrical properties, corrosion resistance and biomedical application has stimulated a growing interest in their mechanical properties and especially hardness testing that is routinely used for coating evaluation. In this study Jönsson and Hogmark model is applied for the porous hydroxyapatite produced by plasma spraying on Ti6A14V substrate. Firstly, the effect of indentation load on hardness values of coating and substrate are studied. The modified Jönsson and Hogmark model is used to explain the composite hardness behavior and the effect of coating porosity.
\end{abstract}

Keywords- Hardness, Coating, Hydroxyapatite, Plasma-spray, porosity

\section{INTRODUCTION}

The hardness test, because of its simplicity, is commonly used to estimate the mechanical properties of coatings. There are several approaches to measuring coating hardness. For thin coatings, a modeling approach can be used to determine the coating hardness and indentation size effect (ISE) behavior. For the Vickers pyramid indenter, the hardness is defined as the load divided by the surface area of the impression. The Vickers hardness number (VHN) is defined as the ratio of load to the total area of impression. According to the usual practice VHN is expressed in $\mathrm{kgfmm}^{-2}$ and the units are omitted.

Two main problems arise when this technique is applied to coated materials:

a) The coating thickness varies typically between $2000 \mathrm{~A}^{\circ}$ for an ion-implanted substrate to 20 micron for the hard coatings used to improve the wear resistance of tool steels. To obtain the bulk hardness value for the film it is necessary to satisfy requirement that the film thickness should be ten times greater than the penetration depth [1]. As the indentation depth is $\mathrm{D}=\mathrm{d} / 7$, the substrate hardness generally influences the measured hardness values.

b) In the load range commonly used in microhardness characterization (typically 5-1000 gf) the hardness number varies with the applied load. This situation is called the indentation size effect (ISE) and has been attributed to a wide variety of mechanisms $[1,2]$. ISE can be modeled in two ways. The first is empirical and corresponds to a power law.

$$
\mathrm{P}=\mathrm{a} \mathrm{d}^{\mathrm{n}}
$$

This equation is called Meyer relationship. The second is a linear relationship between hardness and the reciprocal length of the impression [3]:

$$
\mathrm{VHN}=\mathrm{H}_{0}+\mathrm{B} / \mathrm{d} .
$$

Where $\mathrm{H}_{0}$ is the absolute hardness and $\mathrm{B}$ is a constant. This equation corresponds to a variation of the indentation diagonal with the applied load [4]:

$$
\mathrm{P}=\mathrm{a}_{1} \mathrm{~d}+\mathrm{a}_{2} \mathrm{~d}^{2} .
$$

With $\mathrm{a}_{2}=\mathrm{H}_{0}$ and $\mathrm{B}=1.8544 \mathrm{a}_{1}$. Some attempts have been made to give a physical significance to Eq. (3) [5]. In our opinion, the size effect in hardness is due to the formation of a pile-up at the immediate edge of the impression [6]. This is confirmed by the investigation of Chaudhri and Winter [7], which show that the pile-up supports a part of the indenter load.

Many attempts have been made to establish a quantitative correlation between the hardness of composite material and that both of coating and substrate. The main models developed are based on the area law-of-mixture [8-15] or the volume law-of-mixture [16-18]. Jönsson et al. proposed that the composite hardness $\mathrm{H}_{\mathrm{C}}$ can be expressed as a weighted mean of the film hardness $\mathrm{H}_{\mathrm{f}}$ and the substrate one $\mathrm{H}_{\mathrm{S}}$

$$
\begin{aligned}
& H_{C}=\left(A_{f} / A\right) H f+\left(A_{s} / A\right) H s . \\
& A_{f} / A=2 k t / d-(k t / d)^{2} .
\end{aligned}
$$

Where $\mathrm{A}$ is total projected area of the impression, equal to the sum of the projected areas of the rim, $A_{f}$, and the interior, $\mathrm{A}_{\mathrm{S}}$.

The objective of this study was to evaluate the hardness of porous hydroxyapatite coated onto Ti6A14V substrate. 


\section{EXPERIMENTAL PROCEDURE}

Plasma spraying is used to produce the composite of hydroxyapatite coating on Ti6A14V substrate. Before spraying, the samples were sandblasted in order to obtain a favorable random surface roughness for mechanical bonding in the coating/substrate interface. Surface roughness $\left(\mathrm{R}_{\mathrm{a}}\right)$ was 2.29 micrometers and coating thickness varies between 100 and 120 micrometers. Indentation were made using a Vickers diamond indenter at peak contact loads between $50 \mathrm{gf}$ and $2000 \mathrm{gf}$ on the surface prepared by the way of polishing. The indentations were made and measured in ambient air and approximately 1 minute elapsed between indenting and measuring.

\section{RESULTS AND DISCUSSION}

The hardness values of substrate $\left(\mathrm{H}_{\mathrm{S}}\right)$ and of composite $\left(\mathrm{HV}_{\mathrm{C}}\right)$ were determined according to general equation of Vickers hardness. The particular points of model are shown in the table 1.

The measured hardness values were to be dependent on coating thickness. The hardness values are plotted in Fig. 1 as a function of the reciprocal indentation depth $1 / \mathrm{d}$.

Table 1. Some particular points of composite, substrate and coating hardness.

\begin{tabular}{llllll}
\hline $\begin{array}{l}\mathbf{d} \\
(\mathbf{m m})\end{array}$ & $\mathbf{K t} / \mathbf{d}$ & $\mathbf{A}_{\mathbf{f}} / \mathbf{A}$ & $\begin{array}{l}\mathbf{H}_{\mathbf{c}} \\
\left(\mathbf{K g f} / \mathbf{m m}^{2}\right)\end{array}$ & $\begin{array}{l}\mathbf{H}_{\mathbf{s}} \\
\left(\mathbf{K g f} / \mathbf{m m}^{2}\right)\end{array}$ & $\begin{array}{l}\mathbf{H}_{\mathbf{f}} \\
\left(\mathbf{K g f} / \mathbf{m m}^{2}\right)\end{array}$ \\
\hline High & 0 & 0 & 233 & 233 & 209 \\
60 & 1 & 1 & 277 & 314 & 277 \\
30 & 2 & 0 & 395 & 395 & 344 \\
\hline
\end{tabular}

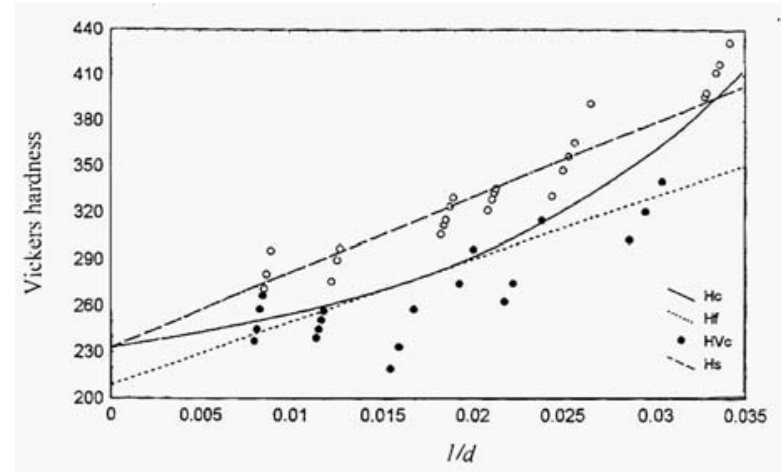

Fig. 1. A Schematic representation of the composite hardness versus $1 / \mathrm{d}$. Tangent at $\mathrm{H}_{\mathrm{C}}$, Model, $\mathrm{H}_{\mathrm{f}}, \mathrm{H}_{\mathrm{s}}$.

At each load, more than six experimental data are recorded to calculate the hardness value.Interpretation of the model based on the area law-of-mixture:
Iost and Bigot [19] consider the relation (4) without the Jönsson and Hogmark simplifications. Taking into account the second- and third-order $1 / \mathrm{d}$ terms, composite hardness can be expressed using the following expansions:

$$
\text { with } \quad \begin{aligned}
\mathrm{H}_{\mathrm{c}} & =\mathrm{H}_{0 \mathrm{~s}}+\mathrm{A}_{1} / \mathrm{d}+\mathrm{A}_{2} / \mathrm{d}^{2}+\mathrm{A}_{3} / \mathrm{d}^{3} . \\
\mathrm{A}_{1} & =2 \mathrm{kt}\left(\mathrm{H}_{0 \mathrm{f}}-\mathrm{H}_{0 \mathrm{~s}}\right)+\mathrm{B}_{\mathrm{S}} \\
\mathrm{A}_{2} & =2 \mathrm{kt}\left(\mathrm{B}_{\mathrm{f}}-\mathrm{B}_{\mathrm{S}}\right)-\mathrm{k}^{2} \mathrm{t}^{2}\left(\mathrm{H}_{0 \mathrm{f}}-\mathrm{H}_{0 \mathrm{~s}}\right) \\
\mathrm{A}_{3} & =-\mathrm{k}^{2} \mathrm{t}^{2}\left(\mathrm{~B}_{\mathrm{f}-} \mathrm{B}_{\mathrm{S}}\right)
\end{aligned}
$$

A mathematic analysis shows that the form of equation (5) depends on the product of $\Delta=\left(\mathrm{H}_{0 \mathrm{f}}-\mathrm{H}_{0 \mathrm{~s}}\right) /\left(\mathrm{B}_{\mathrm{f}}-\mathrm{B}_{\mathrm{S}}\right)$ and kt.

For our experimental data, $\Delta=0.03$ and $\mathrm{k}=0.5$ since cracks formation occur at the corners of the indentation print. This product is less than 0.5.The substrate hardness measured at different applied load after removal of the coating is:

$$
\mathrm{H}_{\mathrm{s}}=233+4871 / \mathrm{d}
$$

Application of Eq. 5 and 6 with the experimental results of the composite hardness aim to obtain the film hardness and its variation with the applied load :

$$
\mathrm{H}_{\mathrm{f}}=209+4061 / \mathrm{d}
$$

It is worth noting that a hardness intrinsic value of 484 $V H N$ has been measured for dense HA.

\section{Conclusions}

One of the most important particularities of hardness measurement is that they are load dependent. In order to obtain an intrinsic value of hardness for the coating/substrate systems, it is possible to use the Jönsson et al. Model. The model based on the area law-of-mixture is suitable at condition that $\mathrm{Kt} / \mathrm{d}$ is less than 1 . Values higher than 1 for $\mathrm{kt} / \mathrm{d}$ correspond to an indent diagonal length less than the coating thickness, and consequently the measured hardness equal the coating one. From the above discussion it is not so difficult to obtain an absolute hardness because the influence of substrate has been found effective only for the highest load. It is also to be noticed that the hydroxyapatite hardness of the coating is less than the bulk hydroxyapatite and substrate ones. This result is a consequence of the presence of porosity in the plasmasprayed hydroxyapatite coating. 


\section{REFERENCES}

1. H. Bückle, in Wesbrook and Conradd (eds), ASM, Metals park, Ohio, (1997), P. 453-491.

2. D. Chicot and J.Lesage, Thin Solid Film, 254, (1995), P. 123.

3. F. Frohlich, P. Grau and W. Grellmann, Phys. Stat. Solidi A, 42, (1977), P. 79.

4. H. Li and R.C. Bradt, J. Mater. Sci., 28, (1993), P. 917.

5. A. Iost, J. Aryani-Bouffette and J. Foct, Mem. Sci. Rev. Met. 11, (1992), P. 681

6. A. Iost and R. Bigot, J. Mater. Sci., 31, 1996, 3573-3577..

7. M. Chaudhri and M. winter, J. Phys. D: Appl. Phys., 21, (1988), P. 370 .

8. B. Jönsson and S. Hogmark, Thin Solid Film, 114, (1984), P. 257.

9. A. Thomas, surf. Eng., 3, (1987), P. 117.

10. L. J. Bredell and J.B. Malherbo, Thin Solid Film, 125, (1985), P. 125.

11. P. A. Engel, E.Y. Hsue and R. G. Bayer, Wear, 162-164, (1993), P. 538.

12. P. A. Engel, A. R. Chitsaz and E.Y. Hsue, Thin Solid Film, 207, (1992), P. 144.

13. S. Betsofen, Russ. Metall. 2, (1993), P. 156.
14. O. Vingsbo, S. Hogmark, B. Jönsson and A. Ingemarsson, (P.J. blau and B.R. Lawn eds.). ASTM, STP, 889, Chap. 15, Philadelphia, (1986), P. 257-271.

15. P. Nemac and V. Navratil, J. Mater. Sci. Lett., 13, (1994), P. 1179.

16. J. R. Tuck, A. M. Korsunsky, D. G. Bhat and S. J. Bull, Thin Solid Film, 148, (1987), P. 51.

17. P.J. Burnett, and D.S. Rickerby, Thin Solid Film, 148, (1987), P. 41.

18. S.J. Bull and D.S. Rickerby, Surf. Coat. Technol., 42, (1990), P. 149.

19. A. Iost and R. Bigot, Surf. Coat. Technol., 80, (1996), P.117.

Address of the corresponding author:

\begin{tabular}{|c|c|}
\hline Author: & Aliasghar BEHNAMGHADER \\
\hline Institute: & $\begin{array}{l}\text { Materials and Energy Research } \\
\text { center }\end{array}$ \\
\hline P.O. Box: & $14155-4777$ \\
\hline City: & Tehran \\
\hline Country: & Iran \\
\hline Email: & a_behnamghader@merc.ac.ir \\
\hline
\end{tabular}

